\title{
WADAH DARI TEMPURUNG KELAPA DI DALAM PERAHU PUNJULHARJO
}

\author{
T.M. Hari Lelono \\ (Balai Arkeologi Yogyakarta) \\ Email: harilono@gmail.com
}

\begin{abstract}
ABSTRAK
Wadah merupakan salah satu perlengkapan hidup manusia yang penting, karena berfungsi sebagai tempat untuk membawa sesuatu baik benda keras, lunak, cair atau biji-bijian tertentu. Wadah sesuai dengan fungsinya menggunakan bahan tertentu seperti misalnya dari tanah liat, daun-daunan, dan buah-buahan yang mimiliki biji yang besar dan kuat.

Di dalam perahu kuna Punjulharjo, di Kabupaten Rembang, Jawa Tengah, suatu hal yang menarik dengan ditemukannya wadah dari tempurung kelapa. Dalam kehidupan beberapa masyarakat-masyarakat tradisional Nusantara masih dikenal penggunaan alat-alat tersebut, sebagai perlengkapan hidup sehari-hari. Penemuan wadah dari bahan tersebut, sekurangnya memberikan gambaran, bahwa tempurung telah dimanfaatkan dan digunakan untuk peralatan oleh nenek moyang.
\end{abstract}

Kata-kata kunci: Perahu kuna, wadah tempurung, digunakan pada masa Jawa Kuna

\section{ABSTRACT}

Container is one of man's living tools which has a function where everything hard or soft, fluid or certain seeds will be placed. Based on its function, container uses spesific materials like clay, leaves and fruits which have big and strong seeds.

In ancient Punjulharjo ship located in Kabupaten Rembang, Central Java, it was found a container made of coconut shell. In the livinghood of some ancient traditional communities, the containers are still used to spport their daily activities. This fact could reveal the time when it had been by the ancestors.

Key words: ancient ship, coconut-shell container, used in the period of ancient Java. 


\section{PENDAHULUAN}

Sepanjang pantai utara Pulau Jawa merupakan dataran yang sangat subur ditumbuhi pohon kelapa (cocos nucifera $L$ ), karena merupakan daerah endapan lumpur dari dataran tinggi di pedalaman Jawa. Pohon tersebut tidak hanya tumbuh di pulau Jawa, tetapi di seluruh pulau-pulau di wilayah Indonesia. Tanaman kelapa dimanfaatkan untuk berbagai keperluan rumah tangga, bahan membuat rumah dan buahnya dikonsumsi untuk bahan makanan. Kesuburan tanaman kelapa tersebut digambarkan pula dalam relief candi-candi di Jawa. Tatahan yang digambarkan pada beberapa relief flora dan fauna yang menghiasi panel-panel relief candicandi di Jawa, salah satunya adalah di Candi Borobudur. Hal tersebut menggambarkan, bahwa pohon nyiur/kelapa merupakan salah satu tanaman yang tumbuh sejak berabad-abad lalu. Selain itu kelapa telah dimanfaatkan dalam berbagai aspek kehidupan masyarakat di Indonesia.

Buah kelapa selain dimanfaatkan sebagai bahan untuk membuat minyak kelapa (minyak goreng), ternyata tempurungnya dapat dimanfaatkan sebagai alat keperluan rumah tangga yang dipergunakan untuk memasak, seperti misalnya di Jawa dikenal dengan nama; sothil, irus, dan gayung. Selain itu ada yang dimanfaatkan sebagai wadah untuk menyimpan bijibijian, air, piring makan dan minum. Pada beberapa masyarakat pedesaan masih ada yang menggunakan alat dari bahan tempurung tersebut, seperti di Bali, Lombok, dan Jawa. Sejak kapan alat-alat dari tempurung mulai digunakan di Indonesia? Belum ada yang mengetahuinya. Apakah sudah digunakan sejak masa prasejarah atau masa sejarah?. Oleh karena rentang waktu yang panjang berkaitan pada masalah periodisasi tersebut, tingkat kemajuan masyarakat manusia dapat dibagi ke dalam tiga periode evolusi, yaitu periode masyarakat berburu atau periode liar (savage), periode beternak atau barbar (barbarism), dan periode pertanian yang berkembang ke arah peradaban atau civilization (Poerwanto, 2006: 48). Berkaitan dengan periodisasi tersebut, penggunaan alat dari tempurung selama ini dalam penelitian arkeologis belum pernah ditemukan. Penelitian-penelitian yang dilakukan oleh Balai Arkeologi Yogyakarta di daerah D.I. Yogyakarta, Jawa Tengah, dan Jawa Timur, sebagai contoh: Penelitian Permukiman Lingkungan Candi Tahap II di candi Kalasan dan Banyunibo, Daerah Istimewa Yogyakarta ditemukan wadah, jambangan, mangkok dan piring (Sulistyanto, 1994: 13); Penelitian Pola Permukiman Dataran Aluvial di Pantai Selatan Jawa, ditemukan fragmen-fragmen wadah (Nitihaminoto, 1995: 8); dan Penelitian Permukiman Desa-Desa Masa Majapahit di Mojokerto, Jawa Timur ditemukan fragmen keramik berasal dari Cina masa Dinasti Yuan (13 - 14 M) berupa pecahan mangkuk dan cepuk dari bahan batuan (stoneware) wama abu-abu berglasir putih kehijauan dan coklat kehitaman (Rangkuti, 1999: 17). Dari situs-situs permukiman hasil penelitian tersebut peralatan rumah tangga yang ditemukan kebanyakan dari gerabah, keramik, dan batuan (Stonewere). 
Selama ini peralatan rumah tangga berupa mangkuk, piring, dan jambangan bunga, dibuat dari tanah liat/lempung, kemudian pada perkembangan penguasaan teknologi gerabah tersebut ada yang dilapisi glasir di bagian permukaan dengan bahan keramik, sehingga menghasilkan bentuk yang indah dan kuat. Semua jenis wadah tersebut dalam proses pembuatannya diperlukan penguasaan teknologi yang memadai dan dapat diproduksi secara masal sebagai bahan komoditas perdagangan. Sementara itu, dengan ditemukannya wadah dari tempurung dalam perahu kuna Punjulharjo tidak memerlukan proses pembuatan yang panjang dan penguasaan teknologi tertentu. Wadah ini dapat dibuat sendiri oleh masyarakat Jawa Kuna untuk mencukupi kebutuhannya sendiri-sendiri.

Tanaman kelapa (cocos nucifera $L$ ) terdapat hampir di seluruh wilayah Indonesia, dan dapat hidup dengan subur di dataran rendah dari pantai bahkan sampai di ketinggian 800 meter. Dalam beberapa bahasa daerah di Nusantara disebut dengan nama Nyiur (Minangkabau), Nyuh (Bali), Kambil/krambil (Yogyakarta). Dalam bahasa Jawa Kuna kelapa disebutkan dengan nama karapa (Zoetmulder, 1982: 804).

Suatu hal yang menarik, ketika dilakukan penelitian tentang perahu kuna di Situs Punjulharjo, ditemukan beberapa buah artefak dengan menggunakan bahan dari tempurung kelapa (Jawa: bathok). Penemuan artefak tersebut tentunya memberikan informasi yang penting, karena belum diketahui sejak kapan artefak atau alat-alat rumah tangga dari bahan tempurung mulai digunakan oleh nenek moyang bangsa kita. Oleh karena itu, penemuan tersebut menambah kasanah pengetahuan, tentang kearifan lokal nenek moyang di daerah pesisir Pantai Utara Jawa dalam upaya untuk mengatasi kebutuhan hidup sehari-hari dengan memanfaatkan potensi sumberdaya alam dan lingkungan yang ada di sekitarnya.

\section{PERAHU PUNJULHARJO}

Pada bulan Juli 2008 penduduk Desa Punjulharjo, Kabupaten Rembang, Jawa Tengah menemukan bangkai perahu kuna di sebidang tanah tambak untuk membuat garam. Pada saat menggali tanah di kedalaman sekitar 2 meter dtemukan perahu kayu dalam posisi membujur timur-barat. Berdasarkan laporan penduduk tersebut, selanjutnya pada bulan Desember 2008 dilakukan peninjauan oleh tim Balai Arkeologi Yogyakarta yang diketuai oleh Novida Abbas bersama dengan Prof. P.Y. Manguin, seorang ahli arkeologi maritim dari EFEO (Prancis). Perahu dengan ukuran panjang 15 meter, dan lebar yang tersisa adalah 4.6 meter tersebut, menggunakan bahan dari kayu dengan teknik penyambungan menggunakan pasak kayu dan tali ijuk untuk mengikat. Melihat bentuk, bahan, ukuran, perahu tersebut sangat menarik untuk diketahui, adalah sejak kapan perahu tersebut dibuat? Maka, dilakukanlah analisis radiokarbon terhadap sampel tali ijuk pengikat kapal. Sampel tersebut dikirim oleh Prof. P.Y. Manguin ke Beta Analytic Radiocarbon Laboratory 
(Miami, Florida, USA). Hasil pengujian dengan radiocarbon dating tersebut menunjukkan kalibrasi antara 660-780 AD, atau sekitar abad ke-7 dan ke-8 Masehi (Novida, 2009: 10).

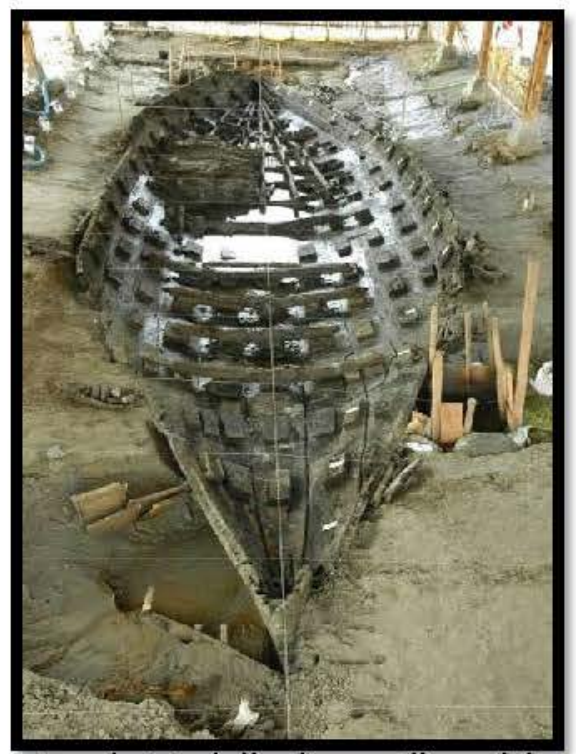

Perahu Punjulharjo, penelitan oleh Balai Arkeologi Yogyakarta Tahun 2009. Dok Balar-YK

Pada tahun 2009 dilakukan penelitian lanjutan yang lebih intensif untuk memperoleh data mengenai konstruksi dan teknologi pembuatan perahu, maupun temuan lain berupa artefak, ekofak, maupun fitur. Menurut Prof P.Y. Manguin, teknologi pembuatan perahu di Asia Tenggara kepulauan telah berkembang sebuah tradisi pembuatan perahu dengan teknologi yang khas, yaitu penggunaan ikatan tali ijuk dan pasak kayu untuk membentuk badan perahu, atau yang dikenal sebagi teknik papan ikat dan kupingan pengikat (sewn-plank and lushed-plug technigue). Tonjolan segi delapan atau tambuku digunakan untuk mengikat papan-papan maupun mengikat papan-papan dengan gading-gading, yaitu dengan menggunakan tali ijuk (arenga pinnata). Selanjutnya pasak kayu digunakan untuk memperkuat ikatan tali ijuk. Teknik pembuatan perahu seperti ini diduga sudah muncul sejak awal Masehi (Novida, 2009: 2)

Oleh karena itu, penemuan perahu tersebut termasuk spektakuler, karena selama ini di Indonesia belum pernah ditemukan perahu kuna yang relatif masih utuh, utamanya berkaitan dengan kontruksi dan teknologi perahu kuna. Perahu kuna ini ditemukan tertanam dalam lumpur dengan jarak sekitar 500 meter dari garis pantai pesisir utara Jawa. Karena posisinya yang terbenam dalam lumpur menyebabkan perahu tersebut secara alami terkonservasi oleh lumpur, pasir, dan air payau. Hal tersebut menyebabkan ketika ditemukan badan perahu masih dalam kondisi relatif utuh. Kondisi tersebut sangat menguntungkan bagi penelitian ini, karena banyak informasi yang akan dapat diketahui dengan jelas utamanya pada aspek teknologi, bahan, dan bentuk perahu kuna. Berdasarkan hasil penelitian, ternyata teknologi penyambungan papan-papan menggunakan pasak kayu yang diperkuat dengan ikatan tali ijuk dengan teknik dan model yang bervariasi. Teknik penyambungan komponen perahu dengan cara diberi lubang/bor pada bagian-bagian tertentu, kemudian lubang-lubang tersebut ditutup/dimasuki dengan pasak kayu/bambu. Teknik pengikatan dengan tali ijuk sebagai penguat sambungan terdapat bermacam variasi pengikatan, ada dengan cara menyilang dan menjahit dengan harapan selain kuat juga dapat menambah nilai estetikanya. Teknik pengikatan 
dengan tali ijuk, selama ini tidak pernah ditemukan pada situs-situs shipwreck dalam penelitian dan konservasi arkeologi bawah air. Belum pernah ditemukannya teknik ikatan tersebut, kemungkinan terbesar karena bahan ijuk mudah busuk dan rusak.

Untuk mengetahui bahan yang digunakan perahu Punjulharjo, diambil beberapa sampel kayu untuk dianalisis. Kayu yang diambil untuk sampel adalah papan perahu yang merupakan bagian dari badan perahu, kayu panjang yang melintang di atas gading, dan pasak kayu. Sampel kayu tersebut dianlisis di Laboratorium Struktur Kayu di Fakultas Kehutanan, Universitas Gadjah Mada. Hasil analisis sampel kayu menunjukkan bahwa papan perahu berasal dari Suku Sapotacege Marga Palaquium Spesies Palaquium spp. Atau yang dikenal sebagai kayu nyatoh. Sementara itu, sampel kayu panjang merupakan Suku Olacaceae Marga Scorodocarpus Spesies $S$. Bomeensis, atau yang dikenal sebagai kayu kulim. Sampel pasak kayu berasal dari Suku Myrtaceae Marga Melaleuca Spesies Melaleuca leucadendron, atau yang juga dikenal sebagai kayu putih (Novida, 2009: 16). Oleh karena itu, sekurangnya digunakan tiga jenis bahan kayu yang fungsinya berbeda-beda, seperti bahan untuk bagian badan perahu berbeda dengan bahan untuk bagian tambuku, penyangga dan kayu panjang yang diletakkan melintang di atas gading.

\section{WADAH DAN FRAGMEN TEMPURUNG YANG DITEMUKAN}

Perahu Punjulharjo ditemukan terpendam dalam lumpur di daerah pantai, di dalam perahu ditemukan beberapa artefak seperti fragmen keramik, tembikar, kayu dan tempurung. Ditinjau dari bahan dan bentuk fgramen-fragmen tersebut, kemungkinan dulu berfungsi sebagai alat yang dipergunakan sebagai wadah. Wadah di dalam Kamus Besar bahasa Indonesia merupakan tempat untuk menaruh, menyimpan sesuatu (1997: 1122). Dari bermacam jenis artefak tempurung dan wadah yang ditemukan seluruhnya berjumlah 51 buah yang terdiri dari fragmen artefak sebanyak 42 buah, tempurung kelapa satu buah (belum diketahui fungsinya) dan wadah dari tempurung sebanyak delapan buah. Wadah yang masih utuh tersebut di temukan dalam Kotak Ekskavasi No $12-15$, ke delapan wadah tempurung tersebut ketika ditemukan masih dalam kondisi utuh, tetapi setelah diangkat kepermukaan lama-kelamaan menjadi rapuh dan hancur karena pengaruh perbedaan temperatur dalam kotak gali yang dingin, sedangkan suhu di permukaan tanah lebih panas. Suatu hal yang cukup menarik, adalah dari delapan wadah tersebut terdapat sebuah artefak dengan bentuk bulat dengan 14 buah lubang, yaitu sebuah lubang di tengah yang dikelilingi oleh 13 lubang lainnya. Diduga lubang-lubang tersebut digunakan untuk simpul-simpul tali menyambung dengan jaring. Memang tempurung tersebut bentuknya bulat dan tipis, sehingga bentuknya tidak mirip dengan wadah-wadah lainnya yang ditemukan. 
Dari delapan belas Kotak Ekskavasi, ditemukan wadah dari tempurung yang relatif utuh dan masih utuh hanya di empat kotak, yaitu Kotak Ekskavasi Nomor 12, 13, 15 dan18. Dalam setiap kotak ekskavasi berukuran 1 meter $\times 6$ meter terdapat beberapa gading-gading yang berfungsi sebagai kerangka perahu. Setiap tempurung yang ditemukan bentuk dan ukurannya bervariasi, namun mayoritas temuan tersebut diduga berfungsi sebagai wadah. Berikut akan diuraikan beberapa sampel dari hasil kotak-kotak ekskavasi tersebut, antara lain:

\section{Kotak Ekskavasi Nomor 12, dan 15}

Ditemukan tempurung kelapa dalam Kotak 12 dengan ukuran tinggi $7 \mathrm{~cm}$ dan lebar $15 \mathrm{~cm}$. Apabila dibandingkan dengan temuan wadah yang lainnya, ukuran tersebut relatif paling lebar dan tinggi, diduga perbedaan ukuran tempurung tersebut memiliki fungsi yang berbeda.

Temuan wadah dari tempurung tersebut, disayangkan sebagian telah rusak karena terkontaminasi dengan udara luar. Ketika baru ditemukan terendam di dalam lumpur kondisinya masih utuh, tetapi setelah diukur dan diangkat ke luar kotak ekskavasi, kemudian menjadi sangat rapuh dan hancur berkeping-keping. Dalam gambar berikut (gambar rekontruksi) merupakan bentuk tempurung yang semula utuh, setelah diangkat menjadi rusak. Kedua wadah tersebut memiliki bentuk yang berbeda, karena menggunakan bahan (kelapa) yang berbeda. Bentuk yang di atas ditemukan dalam Kotak Ekskavasi Nomor $12-13$, adalah dari jenis kelapa yang pada umumnya diolah sebagai bahan minyak kelapa. Sedangkan bentuk yang di bawahnya ditemukan dalam Kotak Ekskavasi Nomor 15, menggunakan jenis kelapa yang relatif kecil.

Di Kotak Nomor 15 ditemukan tempurung dengan ukuran $11.5 \mathrm{~cm}$ dengan lebar $9 \mathrm{~cm}$. Dilihat dari bahannya digunakan dari jenis buah kelapa tertentu yang memang berukuran lebih kecil, tetapi memiliki kekuatan dan kekerasan yang sama.

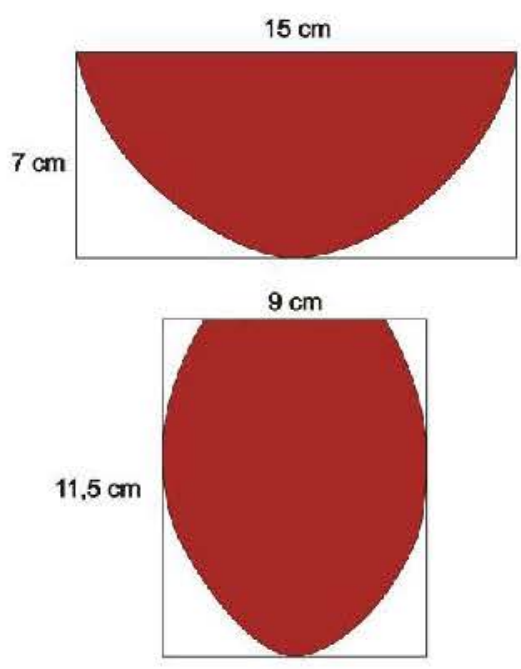

Gambar rekontruksi: Gambar atas Kotak 12 13/Gading 11 Gambar bawah Kotak 15/Gading 14 Dari bentuk asli buah kelapa, yang dimanfaatkan sebagai wadah sekitar $80 \%$. Pada bagian atas yang lonjong dipangkas rata, pada bagian sisi luar dan dalam dihaluskan. Wadah dengan bentuk seperti ini, diduga berfungsi untuk mengambil air, tempat minum, menyimpan garam dan biji-bijian. 
Hal yang menarik perhatian pada tempurung kecil dengan bentuk lonjong (elip) tersebut tidak terdapat lubang kecil pada sisi samping atasnya, seperti lazimnya pada beberapa alat dari bahan tempurung tradisional yang berfungsi untuk memasukkan tangkai dari bahan bambu. Alat sejenis itu, biasanya digunakan untuk mengambil air, ramuan, cendol/dawet, dan untuk mengambil/meramu jamu tradisional.

\section{Kotak Ekskavasi Nomor 18 posisi pada Gading 11}

Ditemukan tempurung kelapa ukuran tinggi $5.5 \mathrm{~cm}$ dengan lebar

$11 \mathrm{~cm}$. Bagian bawah tempurung berbentuk lonjong tanpa ada lubang. Pada bagian dalam tempurung tampak dihaluskan, tetapi pada bagian sisi luarnya tidak dihaluskan. Diduga tempurung tersebut digunakan untuk menguras air yang masuk ke dalam perahu.

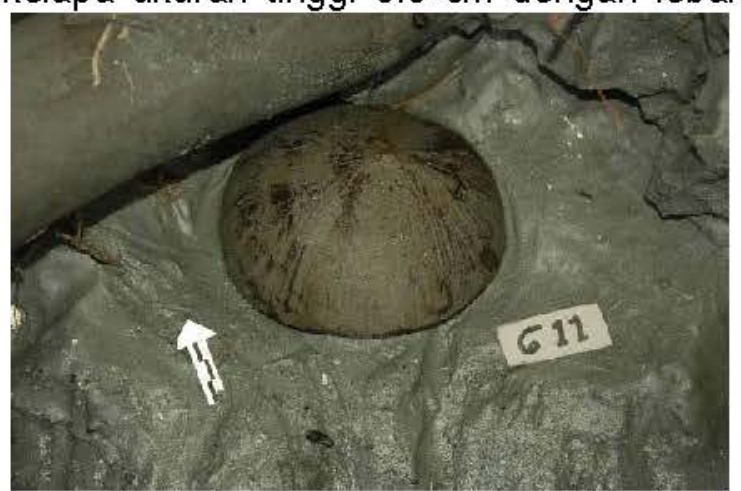

Wadah dari templurung Perahu Pumjutharjo, ekskavasi Balai ArkeologiYogyakarta. Tahuin 2009. Dok Balar-YK

\section{Kotak Ekskavasi Nomor 18. posisi pada Gading 17}

Dalam ekskavasi kotak ini di bawah Gading No 17, ditemukan empat buah tempurung dalam kondisi relatif utuh, pada bagian tepi terdapat retakan karena terkontaminasi udara. Sebanyak dua buah temuan kemudian dijadikan sebagai sampel. Tempurung yang pertama, berukuran: lebar $14 \mathrm{~cm}$ dan tinggi $7 \mathrm{~cm}$. Wadah ini menggunakan bahan separuhnya $(50 \%)$ dari buah kelapa. Pada bagian dasar wadah bentuknya hampir datar, sehingga jika diletakkan di lantai tidak akan goyah, sedangkan pada ke dua sisinya (dalam dan luar) tampaknya dihaluskan, sehingga terkesan rapi; Tempurung yang kedua, berukuran relatif besar dengan lebar $15 \mathrm{~cm}$ dan tinggi $7 \mathrm{~cm}$ dalam kondisi bagian atas dipotong dengan bekas potongan yang rata. Secara keseluruhan bentuk dasar dan dinding bagian dalam dan luarnya sama dengan wadah yang pertama. Sayangnya artefak ini kemudian rusak retak-retak setelah terkontaminasi dengan udara luar. Diduga wadah ini berfungsi sebagai piring makan, karena kedua sisi bagian dalam dan luarnya dihaluskan.

Dari hasil penelitian Perahu Punjulharjo dengan ditemukannya wadah dari tempurung kelapa tersebut, dilihat dari bahan, bentuk dan ukurannya dapat digolongkan menjadi tiga macam bentuk wadah, antara lain: 
1. Bentuk yang pertama, berupa wadah dengan ukuran lebar $15 \mathrm{~cm}$ dan tinggi $7 \mathrm{~cm}$, menggunakan sekitar $40 \%$ dari sebuah kelapa, dengan ukuran tersebut termasuk menggunakan bahan kelapa yang berukuran relatif besar. Bentuk dam ukuran wadah seperti itu, dalam masyarakat Jawa sering disebut dengan nama bathok, di Bali disebut kekau/kau. Nama 'bathok', sebenarnya adalah nama tempurung kelapa, istilah tersebut kemudian lebih sering diucapkan untuk menyebutkan wadah tempurung kelapa yang biasanya dipergunakan untuk untuk mengambil (menciduk) air. Sementara itu, wadah dengan ukuran yang lebih kecil tetapi bagian bawahnya datar, biasa digunakan untuk tempat minum.

2. Bentuk yang kedua, wadah ini bentuknya berbeda dengan yang pertama, selain kelapa yang digunakan berukuran lebih kecil bentuknya lonjong. Wadah yang bentuknya elip ini berukuran lebar $9 \mathrm{~cm}$ dan tinggi $11.5 \mathrm{~cm}$, untuk membuatnya diperlukan $70 \%$ dari bentuk aslinya. Masyarakat Jawa/Bali biasanya menggunakan wadah ini sebagai tempat untuk: (a) Alat untuk mengaduk/menuang cairan/jamu, tetapi biasanya terdapat lubang di sisi luarnya untuk memasang tangkai; (b) Sebagai tempat menyimpan biji-bijian, tetapi biasanya di bagian atasnya diberi tutup.

3. Bentuk yang ketiga dengan lebar $15 \mathrm{~cm}$ dan tinggi $7 \mathrm{~cm}$, merupakan tempurung yang berukuran paling besar. Pada kedua sisinya di dalam dan luar dihaluskan sehingga berwama hitam dan tipis, bentuk seperti ini kemungkinan digunakan sebagi tempat makan.

Dari sebanyak 51 buah temuan yang terdiri dari 42 fragmen, satu buah tempurung berbentuk bulat dan delapan buah berupa wadah tersebut, belum dapat diketahui fungsinya secara pasti. Berkaitan dengan hal tersebut, di beberapa masyarakat tradisional masih mengenal dan menggunakan alat-alat serupa untuk keperluan alat-alat rumah tangga sehari-hari. Namun dengan adanya persamaan bentuk tersebut, apakah kemudian dapat disejajarkan bentuk-bentuk artefak dengan benda-benda etnografis begitu saja, sebagai bahan analogi tentang fungsi, nama dan lain sebagainya?. Sebuah benda (artefak) dari masa lalu yang bentuknya sama/mirip, belum tentu memiliki fungsi yang sama dengan benda etnografis dewasa ini. Oleh karena itu, adanya penemuan wadah dari tempurung, akan dicoba untuk dicarikan data etnografi yang masih digunakan di dalam kehidupan sehari-hari masyarakat, sebagai bahan analogi.

Mengenai hal tersebut Daud Aris Tanudirdjo memberikan penjelasan untuk mereview kembali permasalahan etnoarkeologi di Indonesia dalam judul Memikirkan Kembali Etnoarkeologi, menyatakan ... Hal ini dapat dicontohkan dengan melihat pada 'benda aslinya' atau benda arkeologi jika utuh, yang ternyata berbeda dengan benda etnografis... Jadi, cukup jelas bahwa etnoarkeologi tidak dapat menjadi bukti yang memastikan bahwa fenomena arkeologi akan sama dengan yang dapat diamati di masa kini (etnografi) (Tanudirdjo, 2009; 7). Berdasarkan pada pernyataan tersebut, 
bahwa wadah yang ditemukan dari segi bentuk maupun fungsi belum dapat dipastikan akan sama dengan yang digunakan oleh masyarakat saat ini.

Temuan wadah di perahu Punjulharjo, mengingatkan pada bendabenda etnografi peralatan rumah tangga dari bahan tempurung yang masih digunakan oleh beberapa masyarakat di Indonesia, khususnya di Jawa, Bali dan Lombok. Di pasar tradisional Kotagede Daerah Istimewa Yogyakarta, masih ada pedagang yang menjual peralatan dapur tersebut. Salah satu pedagang bemama Ibu Jumini (65 Tahun) berasal dari Desa Samakan

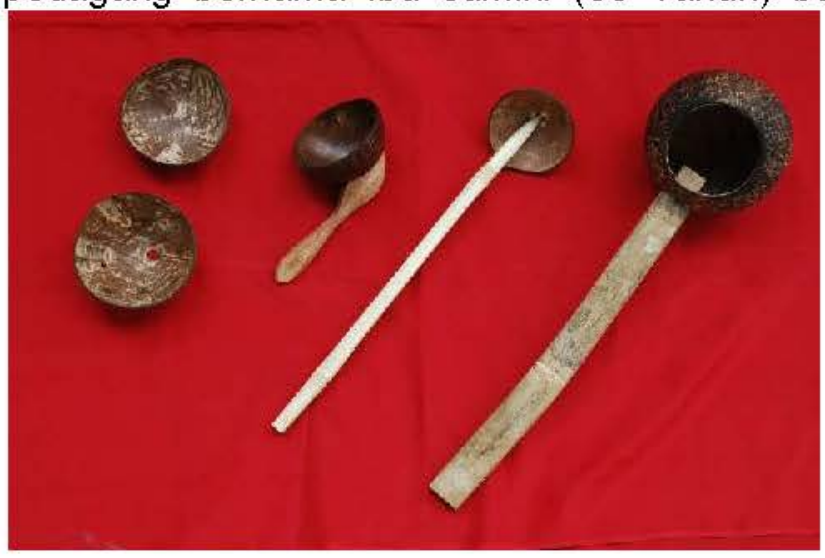

Kotagede, menjual alatalat dapur yang terdiri dari: Siwur digunakan untuk mengambil air; Irus terdiri dari tiga ukuran/jenis irus gede, irus jangan dan irus kuwung masing-masing memiliki fungsi yang berbeda-beda. Secara umum fungsinya adalah untuk mengambil sayur, jamu dan mengaduk masakan; Enthong, digunakan untuk mengambil nasi; Nguling digunakan untuk minum jamu; Nyaton berfungsi sebagai angsang untuk mengukus masakan; Beruk, digunakan untuk menakar beras yang akan dimasak, pada bagian bawahnya terdapat sebuah atau kadang tiga lubang dan; Bathok, fungsinya untuk mengambil/memindahkan air. Seperti di Bali dan Jawa ada yang digunakan untuk piring makan, temuan wadah di Punjulharjo tersebut sebagian besar bentuknya sama dengan yang digunakan sebagai tempat makan (piring). Peralatan rumah tangga menggunakan bahan tempurung, cara membuatnya cukup mudah hanya diperlukan peralatan berupa pisau khusus yang tajam dengan bentuk bagian ujung pisau berbentuk agak elip. Menurut Suroto (70 tahun) suami Ibu Jumini, untuk membuat piring bathok bahan yang diperlukan berupa sebuah kelapa yang telah diambil isi/buahnya. Setelah dibelah sesuai bentuk yang diinginkan, bagian atas yang ada lubangnya dibuang. potongan tersebut dihaluskan dan dirapikan dengan menggunakan pisau. Bagian sisi dalam dan luar juga harus dikerok/dihilangkan lapisan atasnya menggunakan pisau khusus. Tahap selanjutnya, adalah untuk finising bagian permukaan dihaluskan dengan amplas atau menggunakan daun jati dicampur dengan pasir, setelah rata dan halus tempurung tersebut berubah warna menjadi kehitam-hitaman.

Berdasarkan pada pengalaman masyarakat petani, di masa lalu masih menggunakan tempurung sebagai alat utama untuk menyimpan sesuatu barang. Sebagai contoh, tempurung bentuk elip dengan ukuran lubang yang kecil $(9 \mathrm{~cm})$ dan tinggi $(11,5 \mathrm{~cm})$ tersebut biasanya diberi tutup dan berfungsi untuk menyimpan biji-bijian yang akan ditanam. Wadah tempurung tersebut lebih tahan terhadap cuaca di lingkungannya, sehingga 
dapat mengurangi kelembaban dan suhu di dalam tetap kering. Selain bermacam fungsi tersebut, sampai kini di daerah pedalaman masih ada yang digunakan untuk menyimpan garam dapur, tetapi pada bagian atasnya tidak pakai tutup.

Penemuan wadah tempurung yang ditemukan di daerah pesisir utara Jawa, sekurangnya telah memberikan informasi penting bagi kita, bahwa alat-alat tersebut kemungkinan bagian dari peralatan rumah tangga, telah digunakan oleh kalangan nelayan sudah sejak masa sekitar abad ke-7 Masehi. Suatu hal yang lebih penting dalam temuan tersebut, sebenarnya bukan pada banyak jenisnya alat-alat/wadah yang ditemukan, tetapi adalah pada pengenalan dan pemanfaatan potensi alam yang ada dan potensi tersebut telah diapresiasi oleh nenek moyang, sebagai suatu kearifan lokal (local genius). Nilai-nilai tersebut, dalam konteks penguasaan tekonologi tepat guna yang berbasis back to nature sangat penting untuk disosialisasikan kepada generasi muda Indonesia yang semakin tidak peduli dan tidak mengenali jatidirinya, serta potensi budaya yang diwariskan oleh nenek moyang. Alat rumah tangga dari bahan tempurung, sampai saat ini masih dapat dijumpai di daerah-daerah pelosok pedesaan, bahkan masih banyak dijual di pasar-pasar tradisional, karena alat-alat tersebut selain awet, tidak berbau dan tidak panas jika digunakan. Selain sebagai alat rumah tangga, tempurung bahkan dijadikan bahan cendera mata/kerajinan yang banyak digemari oleh wisatawan lokal maupun mancanegara.

Kemampuan mengolah dan memanfaatkan alam sekitamya yang dikuasai oleh nenek moyang, merupakan bentuk penguasaan teknologi. Hal itu dapat dijadikan modal untuk disampaikan/diajarkan kepada generasi muda, bahwa para pendahulunya dalam mengatasi hidup selalu beradaptasi, menguasai dan memanfaatkan alam. Kemampuan tersebut, merupakan salah satu ciri jatidiri bangsa yang tentunya dapat dibanggakan.

\section{PENUTUP}

Temuan artefak dari bahan tempurung di perahu Punjulharjo, telah memberikan informasi penting bagi dunia arkeologis, utamanya dalam pemanfaatan sumberdaya lingkungan alam yang ada dalam aspek teknologi. Selama ini, dalam kehidupan suku-suku yang tersebar luas dalam masyarakat Indonesia, dapat dipastikan mereka mengenal dan menggunakan alat-alat rumah tangga dari bahan tempurung, dimana pohon kelapa dapat hidup dengan subur. Bukti arkeologis berupa artefak tersebut, telah membuka cakrawala dunia pengetahuan khususnya arkeologi, tentang sejak kapankah nenek moyang Bangsa Indonesia menggunakan peralatan rumah tangga dari bahan tempurung.

Berdasarkan data etnografi penggunaan alat rumah tangga dari bahan tempurung pada beberapa masyarakat tradisional yang sampai kinipun masih dapat dijumpai di pedesaan-pedesaan. Data etnografis tersebut hanyalah merupakan salah satu acuan sebagai pembanding yang 
mengarah pada suatu penjelasan yang akurat dan argumentatif. Sebagai contoh, beberapa wadah yang ditemukan di dalam perahu Punjulharjo, bentuknya sama dengan benda-benda etnografi yang masih digunakan oleh masyarakat. Dari bentuk yang sama belum tentu memiliki fungsi yang sama, karena pada masa lalu belum tentu digunakan untuk menyimpan makanan, walaupun pada masa kini digunakan untuk menyimpan makanan. Hal tersebut sering terjadi, karena satu buah benda bisa memiliki lebih dari satu fungsi (multi fungsi).

Pada bagian pendahuluan telah disebutkan, dalam perahu Punjulharjo ditemukan beberapa macam alat-alat dari bahan tempurung dengan bermacam bentuk dan ukuran. Hal tersebut, sekaligus membuktikan bahwa nenek moyang yang hidup di daerah pantai, khususnya para nelayan telah memanfaatkan tempurung sebagai bahan untuk peralatan rumah tangga yang salah satu fungsinya sebagai wadah.

Adanya wadah dengan tiga bentuk yang berbeda tersebut, tidak dapat dengan mudah kemudian dianalogikan dengan benda etnografis yang masih digunakan oleh beberapa masyarakat saat ini. Namun, sekurangnya benda etnografis dapat dijadikan sebuah informasi berdasarkan kriteriakriteria tertentu yang kemungkinannya mendekati kebenaran tentang bentuk dan fungsinya. Dari segi bentuk jelas ada persamaan, permasalahannya dari segi fungsional belum tentu sama. Berdasarkan data-data artefaktual dan etnografis tersebut, kiranya masih perlu dilakukan kajian yang mendalam secara komprehensif tentang bentuk dan fungsi wadah tersebut. Diketemukannya wadah dari tempurung di dalam Perahu Punjulharjo Abad ke 7 - 8 Masehi tersebut, membuktikan bahwa nenek moyang pada masa Jawa kuna telah pandai memanfaatkan lingkungan alam (flora) untuk mengatasi hidupnya. 


\section{KEPUSTAKAAN}

Nitihaminoto, Goenadi, 1995. Penelitian Pola Permukiman Dataran Tinggi Aluvial Pantai Selatan Jawa Tahap V. Situs Krakal, Sidorejo, Tepus Gunungkidul. Laporan Penelitian Arkeologi (LPA). Balai Arkeologi Yogyakarta.

Novida Abbas, 2009. Penelitian Perahu Kuna, Punjulharjo Rembang, Jawa Tengah. Laporan Penelitian Arkeologi (LPA). Balai Arkeologi Yogyakarta.

Zoetmulder, P.J. 1982. Old Javanese - English Dictionary Part I A-O. S Gravenhage - Martinus Nijhoff. Leiden, Nederlands

Poerwanto, Hari, 2006. Kebudayaan dan Lingkungan Dalam Perspektif Antropologi. Pustaka Pelajar. Yogyakarta.

Rangkuti, Nurhadi. 1999. Pola Permukiman Desa-Desa Masa Majapahit di Timur Jawa Timur: Kabupaten Mojokerto dan Pasuruan, Jawa Timur. Laporan Penelitian Arkeologi (LPA), Balai Arkeologi Yogyakarta.

Sulistyanto, Bambang, 1994 Penelitian Permukiman Lingkungan Candi Tahap 1I. Situs Candi Kalasan dan Candi Banyunibo, Sleman, Yogyakarta. Laporan Penelitian Arkeologi (LPA), Balai Arkeologi Yogyakarta

Tanudirdjo, Daud Aris, 2009. "Memikirkan Kembali Etnoarkeologi". Papua. Vol 1 No 2 November. Balai Arkeologi Jayapura.

Brosur Departemen Kebudayaan dan Pariwisata. Direktorat Jenderal Sejarah dan Purbakala. Direktorat Peninggalan Bawah Air. 2005.

Kamus Besar Bahasa Indonesia, 1997. Departemen Pendidikan dan Kebudayaan. Balai Pustaka

http://mazzbuddy.multiply.com/journal

Informan: Ibu Jumini (65 tahun) dan Bapak Suroto (70 tahun), Pedagang alat-alat dapur tradisional di Pasar Kotagede, Yogyakarta. Alamat Desa Samakan, Kotagede, Yogyakarta. Wawancara dilakukan Tgl 13 September 2011, Pukul 13.30 WIB. 